\title{
Improved biofertilizer properties of digestate from codigestion of brewer's spent grain and palm oil mill effluent by manure supplementation
}

\author{
Uduak U. Ndubuisi-Nnaji1, Utibe A. Ofon ${ }^{1 *}$, Nicanor I. Ekponne ${ }^{1}$ and Nnanake-Abasi O. Offiong ${ }^{2,3^{*}}$ (D)
}

\begin{abstract}
The biofertilizer quality of anaerobically codigested agroindustrial residues from brewer's spent grain and palm oil mill effluent was evaluated after supplementation with different livestock manure in order to validate its use as organic fertilizer. Manure supplementation assay was performed using different animal manure-inoculum to demonstrate the influence of inoculum-type on the nutrient status, plant growth promoting bacteria (PGPB) and other plant growth promoting attributes of the resultant digestate. In addition to elevated nutrient levels $(K>P>$ $\mathrm{Ca}>\mathrm{Mg}>\mathrm{S}>\mathrm{N}$ ), the plethora of essential microbial groups (phosphate solubilizers $>$ diazotrophs $>$ auxin producers) that enhance nutrition and promote plant growth was evinced in the supplemented digestate compared to the control. On the other hand, environmental risk assessment revealed a notable yet inadequate reduction in indicator bacteria and putative pathogens (> $3.0 \log \mathrm{CFU} \mathrm{mL} \mathrm{m}^{-1}$ ) with potentially toxic elements within publicly available requirements. The preponderance of PGPB with excellent biofertilizing attributes observed in this study could be leveraged upon by plants thus substantiating its potential for use as organic fertilizer. However, the presence of pathogens highlights the importance of post-treatment hygienization to eliminate its biosafety risk.
\end{abstract}

Keywords: PGPB, Manure supplementation, Biofertilizer, Environmental risk, Digestate

\section{Introduction}

Nigeria like many other developing countries generates humongous amounts of untreated wastes from several agricultural and industrial operations, including brewer's spent grain (BSG) and palm oil mill effluent (POME) [13]. The breakdown of these organic waste streams has resulted in widespread contamination and deterioration of the ecosphere. However, with the burgeoning population and increasing demand for energy and sustainable environment, interest in waste valorization (treatment/ stabilization) with simultaneous generation of renewable energy continues to intensify. Anaerobic digestion (AD), a

\footnotetext{
* Correspondence: utibeofon@uniuyo.edu.ng; offiong18@mails.ju.edu.cn 'Department of Microbiology, University of Uyo, Uyo 520001, Nigeria ${ }^{2}$ International Centre for Energy \& Environmental Sustainability Research, University of Uyo, Uyo 520001, Nigeria

Full list of author information is available at the end of the article
}

widely used technology in many countries presents a suitable option for the production of biogas from organic wastes $[4,5]$. It involves a controlled biological process whereby biomass (including varying types of organic materials, wastewater treatment sludge, catering and food processing wastes, energy crops, livestock manure and biodegradable plant residues) is transformed by the activity of certain bacteria in an anaerobic environment at suitable temperatures into a desired methane rich biogas, yielding a plant nutrient rich residue (digestate) as byproduct [6]. The transformation processes vary between 15 and $30 \mathrm{~d}$ at mesophilic temperatures $\left(35-42^{\circ} \mathrm{C}\right)$ and $10-20 \mathrm{~d}$ at thermophilic temperatures $\left(45-60^{\circ} \mathrm{C}\right)$. However, some materials require longer times to be sufficiently degraded thus their hydraulic retention time (HRT) which is the average process time of the ingestate in the

(c) The Author(s). 2020 Open Access This article is licensed under a Creative Commons Attribution 4.0 International License, which permits use, sharing, adaptation, distribution and reproduction in any medium or format, as long as you give

appropriate credit to the original author(s) and the source, provide a link to the Creative Commons licence, and indicate if changes were made. The images or other third party material in this article are included in the article's Creative Commons licence, unless indicated otherwise in a credit line to the material. If material is not included in the article's Creative Commons licence and your intended use is not permitted by statutory regulation or exceeds the permitted use, you will need to obtain permission directly from the copyright holder. To view a copy of this licence, visit http://creativecommons.org/licenses/by/4.0/. 
bioreactor, may be as long as $60-80 \mathrm{~d}$ after which most or all of the energy content of the biomass is digested with diminishing biogas production, yielding the resultant residue termed digestate [7].

Besides temperature and HRT, other operating conditions such as the digester (bioreactor) design, feedstock concentration, moisture content, nutrient content, $\mathrm{C} / \mathrm{N}$ ratio and $\mathrm{pH}$ can equally affect the $\mathrm{AD}$ process [8]. Since the $\mathrm{AD}$ process is very complex involving different groups of microorganisms with various environmental requirements, any adjustment in one or more of these operating conditions will influence the growth and performance of the microorganisms and hence the yield and quality of the biogas and digestate [9]. Certain waste/residues with complementary properties can be codigested anaerobically to achieve elevated biogas yields [10-12]. The biogas generated from $\mathrm{AD}$ processes has been utilized as a source of renewable energy in many developed countries with potentials for heating, electricity and vehicle fuel. This is as a result of the high greenhouse gas emissions and other environmental impacts associated with the utilization of fossil fuels $[13,14]$.

Besides biogas, the digestate has been investigated [1517] and identified with soil fertilizing properties, improving soil respiration. Qi et al. [18] reported that the fertilizer properties of mesophilic and thermophilic anaerobic digestates contain varying degree of nutrients and plant growth promoting bacteria (PGPB), while Alfa et al. [15] reported that the use of digestate from AD is already a practice that has led to improved soil management and less toxic chemical consumption in cropping systems. The digestate which is the remains of the $\mathrm{AD}$ process is mostly a semi-solid, fibrous solid and liquid mass containing both organic and inorganic matter. The microbial communities digest most of the organic matter during the $\mathrm{AD}$ process [9], converting them into inorganic compounds. Also, Qi et al. [18] reported that the inorganic nutrients in the digestate are present in plant-utilizable forms at a markedly higher level compared to the feedstock, due to the mineralization of organic matter found in the feedstock during AD. For example, organic nitrogen in the feedstock is converted to bioavailable nutrients (ammonium- $\mathrm{N}$ and nitrates) and is beneficial if the digestate is intended for use as biofertilizer. Certain bacteria under anaerobic conditions have been identified with the ability to not only convert organic $\mathrm{N}$ in feedstock to inorganic plantutilizable forms. Qi et al. [18] evaluated the plant growthpromoting properties of bacterial species and these bacteria were proposed to occupy the rhizosphere of many plant species exerting beneficial effects on plant growth through direct and/or indirect mechanisms. These mechanisms include solubilization of immobilized phosphate in mineral ions into plant-utilizable forms, production of siderophores (iron-chelating agents) which can solubilize iron from minerals or organic compounds under ironlimiting conditions to make iron accessible to plants, synthesis of phytohormones like indole acetic acid for enhanced cell division and root development in plants as well as production of antibiotics and enzymes that combat/suppress phytopathogens.

The recent elevated global application of inorganic fertilizers on soil, coupled with the pressurizing need for an increase in food production to meet the demand of the increasing world population has played a role in addressing notable problems including extreme global soil quality decline. Other concerns arise from the limited bioavailability of nutrients [9] and the relatively high cost of purchase of inorganic fertilizers. These problems urgently suggest the compelling need for the use of organic amendment material (digestate) as a sustainable alternative. The biofertilizer property of any digestate is the usefulness of such digestate in promoting plant growth $[15,19]$. The microorganisms in the digestate may be the normal flora of the original feedstock for the $\mathrm{AD}$ process and/or an inoculation of allochthonous microorganisms from anaerobic sludge to augment the microbial constituent and activity as well as improve the performance of the AD process. Different studies have recorded the use of diverse livestock manure as feedstock for $\mathrm{AD}$ and production of biofertilizers $[9,15,18]$. Several authors [20-22] have also reported the enhancement of biomethane production through bioaugmentation using hydrolytic and acid-degrading bacteria from different sources (peat, soil, anaerobic sludge) but no literature exists on the enhancement of biofertilizer quality of digestate by inoculum addition (through supplementation with microbial community such as those present in livestock manure). The digestate however is not innocuous as it contains heavy metals as well as pathogens (including antibiotic-resistant bacteria) that may be inimical to soil organisms, plants and humans at large $[18,23-25]$. This study aimed at evaluating the relative effects of supplementation with different livestock manure on the biofertilizer quality of the resultant digestate obtained from anaerobic codigestion of BSG and POME by focusing on the plant growth promoting attributes such as phosphate solubilization, nitrogen fixation, auxin (indole-3-acetic acid, IAA) production, bioload of PGPB and nutrient profile of the digestate. In addition, the quantities of potentially toxic elements (PTEs) and indicator bacterial loads of the whole digestate were also assessed to establish its suitability for use as soil conditioner and organic fertilizer.

\section{Materials and methods}

\section{Batch AD}

The AD was performed in a lab-scale batch system using amber borosilicate glass serum bottles (100 mL capacity) 
(Wheaton 223,766, USA) and $20 \mathrm{~mm}$ aluminium crimp seal with PTFE/Butyl septa for headspace vial (Wheaton W224224, USA) as reactors [12]. The experimental design of Cater et al. [20] was adopted for the anaerobic codigestion and manure supplementation assay. BSG and POME used as feedstock and co-substrate were obtained from Champions Brewery Plc and an open pond at Domita Farms, respectively, in Uyo, Nigeria. Livestock manure (cow dung, swine slurry and poultry droppings) used as inoculum was collected from Domita Farms, Uyo, Nigeria. The substrate/inoculum mixture characteristics prior to feeding the reactors are presented in Table 1. The digesters were fed with $55 \mathrm{~mL}$ POME $+10 \mathrm{~g}$ BSG $+5 \mathrm{~g}$ livestock manure except for the control (without livestock manure) and placed in a water bath at mesophilic temperature $\left(40^{\circ} \mathrm{C}\right)$ and reaction time of $30 \mathrm{~d}$. Briefly, there were four (4) reactors (A-D) with the following composition: Reactor A (10 g $\mathrm{BSG}+55 \mathrm{~mL}$ POME $+5 \mathrm{~g}$ cow dung); Reactor B (10 g $\mathrm{BSG}+55 \mathrm{~mL}$ POME $+5 \mathrm{~g}$ pig Slurry); Reactor C (10 g $\mathrm{BSG}+55 \mathrm{~mL}$ POME $+5 \mathrm{~g}$ poultry dropping); Reactor $\mathrm{D}$ (10 g BSG + $55 \mathrm{~mL}$ POME) - control. Digestates were simultaneously discharged from the digesters following exhaustion of biogas production after $30 \mathrm{~d}$ and analysed for the presence of potential PGPB, indicator bacteria and potential pathogens, soil macro- and micronutrients $(\mathrm{N}, \mathrm{P}, \mathrm{K}, \mathrm{Mg}$, and $\mathrm{Ca}$ ) as well as heavy metals ( $\mathrm{Mn}, \mathrm{Zn}, \mathrm{Cu}, \mathrm{Pb}$ and $\mathrm{Ni}$ ).

\section{Microbiological analyses \\ Isolation of potential PGPB and evaluation of biofertilizing characteristics of the digestate}

The potential PGPB were isolated and enumerated on selected media. They were characterized and identified following standard procedures described by Holt et al. [26]. These bacteria were also tested for phosphate solubilizing activity, diazotrophic nitrogen-fixing efficiency and IAA production to determine the biofertilizing potential of the anaerobic digestate.

\section{Phosphate solubilizing potential of bacterial isolates}

To enumerate the total phosphate solubilizing bacteria (PSB), $1 \mathrm{~mL}$ each of appropriate serially diluted sample was seeded into sterile petri dishes and about $20 \mathrm{~mL}$ of Pikovskaya's medium was pour-plated in replicate under aseptic condition following previously reported methods [27]. The plates were incubated at $28 \pm 2{ }^{\circ} \mathrm{C}$ for $7 \mathrm{~d}$. The representative colonies were enumerated and reported as colony forming unit (CFU) by multiplying with the reciprocal of the dilution factor. Bacterial growth was observed as the qualitative evidence of phosphate utilization.

For phosphate solubilisation efficiency, National Botanical Research Institute's phosphate growth medium was prepared by adding $10 \mathrm{~g}$ glucose, $5 \mathrm{~g}$ of insoluble $\mathrm{Ca}_{3}\left(\mathrm{PO}_{4}\right)_{2}$ as a source of phosphate, $5 \mathrm{~g} \mathrm{MgCl}_{2}, 0.25 \mathrm{~g}$ $\mathrm{MgSO}_{4}, 0.2 \mathrm{~g} \mathrm{KCl}, 0.1 \mathrm{~g}\left(\mathrm{NH}_{4}\right)_{2} \mathrm{SO}_{4}$ and $15 \mathrm{~g}$ agar in $1 \mathrm{~L}$ of water [9]. To each plate, a loopful of the test isolate was spot-inoculated unto the surface of the agar plate. The plates were incubated for $7 \mathrm{~d}$ at $37^{\circ} \mathrm{C}$ before observation for a visible halozone formation around the inoculated colony. The ability of the microbial isolate to solubilize insoluble phosphate was expressed by its solubilisation index using Eq. (1) [9].

$$
\text { Solubilization index }(\mathrm{SI}):=\frac{\text { Colony diameter }+ \text { Halozone diameter }}{\text { Colony diameter }}
$$

\section{Isolation of nitrogen-fixing bacteria from digestate}

Digestate samples were serially diluted for the enumeration of diazotrophic bacteria. In sterile petri plates, 1 $\mathrm{mL}$ of appropriate dilution was pour-plated using Burk's nitrogen free medium [9]. The medium contained in a litre; $0.2 \mathrm{~g} \mathrm{MgSO}_{4}, 0.80 \mathrm{~g} \mathrm{~K}_{2} \mathrm{HPO}_{4}, 0.2 \mathrm{~g} \mathrm{KHPO}_{4}, 0.13 \mathrm{~g}$ $\mathrm{CaSO}_{4}, 0.00145 \mathrm{~g} \mathrm{FeCl}_{3}, 0.000253 \mathrm{~g} \mathrm{Na}_{2} \mathrm{MoO}_{4}, 20 \mathrm{~g}$ sucrose and $15 \mathrm{~g}$ agar. Plates were incubated at $30{ }^{\circ} \mathrm{C}$ for 7 d. The potential to fix atmospheric nitrogen was indicated by the ability to grow after incubation.

Nitrogen fixation efficiency was determined using Jensens's nitrogen deficient medium $\left[\mathrm{C}_{12} \mathrm{H}_{22} \mathrm{O}_{11}(20 \mathrm{~g})\right.$, $\mathrm{K}_{2} \mathrm{HPO}_{4}(1 \mathrm{~g}), \mathrm{MgSO}_{4} \cdot 7 \mathrm{H}_{2} \mathrm{O}(0.5 \mathrm{~g}), \mathrm{FeSO}_{4} \cdot \mathrm{H}_{2} \mathrm{O}(0.1 \mathrm{~g})$, $\mathrm{NaCl}(0.5 \mathrm{~g}), \mathrm{Na}_{2} \mathrm{MoO}_{4}(0.005 \mathrm{~g}), \mathrm{CaCO}_{3}(2.0 \mathrm{~g})$, agar

Table 1 Physicochemical characteristics of experimental mixtures

\begin{tabular}{|c|c|c|c|c|c|c|c|c|}
\hline \multirow[t]{2}{*}{ Bioreactor } & \multicolumn{3}{|c|}{ Initial (feed stock) } & \multicolumn{3}{|c|}{ Final (digestate) } & \multirow{2}{*}{$\begin{array}{l}\text { Cumulative } \\
\text { biogas yield } \\
\text { ( } \mathrm{mL} \mathrm{g}^{-1} \mathrm{VS} \text { ) }\end{array}$} & \multirow{2}{*}{$\begin{array}{l}\text { Methane } \\
\text { yield } \\
\text { (mol \%) }\end{array}$} \\
\hline & TS (\%) & VS (\%) & $\mathrm{pH}$ & TS (\%) & VS (\%) & $\mathrm{pH}$ & & \\
\hline $\bar{A}$ & $25.4 \pm 0.15^{d}$ & $8.1 \pm 0.10^{d}$ & $7.3 \pm 0.10^{b}$ & $9.6 \pm 0.10^{\mathrm{a}}$ & $3.8 \pm 0.21^{\mathrm{a}}$ & $5.6 \pm 0.06^{b}$ & 310 & 89.9 \\
\hline B & $21.6 \pm 1.00^{b}$ & $7.3 \pm 0.10^{b}$ & $6.9 \pm 0.10^{a}$ & $13.5 \pm 0.10^{c}$ & $4.6 \pm 0.10^{b}$ & $5.3 \pm 0.10^{\mathrm{a}}$ & 194 & 75.7 \\
\hline C & $23.4 \pm 0.10^{c}$ & $7.9 \pm 0.10^{c}$ & $7.4 \pm 0.10^{b}$ & $11.2 \pm 0.10^{b}$ & $3.8 \pm 0.10^{\mathrm{a}}$ & $5.4 \pm 0.10^{a}$ & 241 & 81.1 \\
\hline D (control) & $19.0 \pm 1.00^{\mathrm{a}}$ & $6.9 \pm 0.10^{a}$ & $6.8 \pm 0.10^{\mathrm{a}}$ & $17.1 \pm 0.10^{b}$ & $6.6 \pm 0.10^{c}$ & $5.2 \pm 0.10^{\mathrm{a}}$ & 41 & 59.3 \\
\hline BSG alone & $19.0 \pm 0.08$ & $14.2 \pm 0.03$ & $7.1 \pm 0.01$ & $15.3 \pm 0.11$ & $9.5 \pm 0.17$ & $6.1 \pm 1.00$ & 35 & 44.4 \\
\hline POME alone & $15.9 \pm 0.15$ & $4.9 \pm 0.01$ & $5.6 \pm 0.10$ & $13.9 \pm 0.06$ & $4.0 \pm 0.09$ & $5.0 \pm 0.12$ & 27 & 37.5 \\
\hline
\end{tabular}

Similar superscript letters mean not significantly different in mean $(p>0.05)$, while different superscript letters mean significantly different $(p<0.05)$; $-\mathrm{D}$ indicate bioreactors with different waste composition $(n=3)$ 
$(15.0 \mathrm{~g})$ in $1 \mathrm{~L}]$. The isolated colonies were streaked on the nitrogen free agar as described by Vimal et al. [28] and incubated for $48 \mathrm{~h}\left(28 \pm 2{ }^{\circ} \mathrm{C}\right)$. Bacterial growth was observed as the qualitative evidence of $\mathrm{N}_{2}$-fixation. Too dark?

\section{Indole-3-acetic acid (IAA) production assay}

Spot test for auxin (IAA) production was performed with a little modification in the methods of Khamna et al. and Hamza et al. [29, 30]. Pure isolates were cultivated on Tryptone Soya Agar medium (Oxoid, UK) supplemented with $\mathrm{C}_{6} \mathrm{H}_{12} \mathrm{O}_{6} \quad(10 \mathrm{~g}), \mathrm{K}_{2} \mathrm{HPO}_{4} \quad(0.5 \mathrm{~g})$, $\mathrm{MgSO}_{4} \cdot 7 \mathrm{H}_{2} \mathrm{O}(0.2 \mathrm{~g}), \mathrm{NaCl}(0.1 \mathrm{~g})$ and yeast extract $(1.0$ g) in $1 \mathrm{~L}$ volume. Following incubation for $48 \mathrm{~h}$ at $28 \pm$ $2{ }^{\circ} \mathrm{C}$, emerging colonies were smeared on filter paper saturated with Salkowski's reagent $(0.5 \mathrm{M} \mathrm{FeCl} 3+40 \%$ $\mathrm{H}_{2} \mathrm{SO}_{4}$ ). Production of IAA was denoted by the appearance of pink colour. In addition, the plates were observed for visible halozones around the colonies for determination of IAA index using Eq. (2) [31].

$$
\text { IAA production index }=\frac{\text { Colony diameter }+ \text { Cavity diameter }}{\text { Cavity diameter }}
$$

\section{Isolation of indicator bacteria and potential pathogens}

The standard plate count method was performed to quantify indicator bacteria and potential pathogens in the digestates. Samples from digesters were serially diluted in phosphate buffered saline $(\mathrm{pH}=7.4)$ to isolate and enumerate the predominant indicator bacteria and selected potential pathogenic species. Sampling was conducted at the initial time $\left(t_{0}\right)$ and final time $\left(t_{\mathrm{f}}\right)$ in all the digesters. The samples were handled under aseptic conditions in a biosafety cabinet. Following a ten-fold serial dilution, $1 \mathrm{~mL}$ of aliquot from $10^{-5}$ dilution were pourplated in triplicates on some selective media (Mannitol Salt agar, Thiosulphate Citrate Bile Salt Sucrose agar, Salmonella Shigella agar, MacConkey agar, Eosin Methylene Blue agar and Schaedler agar) for the enumeration, isolation, characterization and identification of Staphylococcus, Vibrio, Salmonella species, total coliforms, coliforms and anaerobes respectively. All media used in this study were products of Oxoid, UK. The plates were incubated aerobically at $37 \pm 2{ }^{\circ} \mathrm{C}$ according to manufacturer's specifications and observed after $24 \mathrm{~h}$ except for the Shaedler agar plates. For the estimation and isolation of total anaerobic bacteria, Schaedler agar plates were incubated anaerobically using the gaspak anaerobic system with resazurin indicator strip (pink) which turns colourless upon oxygen elimination to ensure the integrity of the anaerobiosis. All isolates were identified based on their morphological and biochemical characteristics
$[26,32]$. Identified species were preserved at $-4{ }^{\circ} \mathrm{C}$ by freezing pure cultures in sterilized skimmed milk with glycerol (10\%) for further analyses.

\section{Analytical methods}

The light ( $\mathrm{Ca}, \mathrm{Mg}, \mathrm{Na}, \mathrm{K})$ and heavy $(\mathrm{Pb}, \mathrm{Cd}, \mathrm{Cu}, \mathrm{Zn}, \mathrm{Ni}$, $\mathrm{Cr}, \mathrm{Hg}$ ) metals contents in the analyzed wastes and resultant digestate were determined using microwave plasmaatomic emission spectrometer according to the guidelines of Standard Method 3120 [33]. Buchi Kjeldahl apparatus was used for measuring Total Kjeldahl nitrogen according to European standard protocol of Association of Official Analytical Chemists while total phosphate was determined following the methods of Kataki et al. [34]. The total solids (TS) and volatile solids (VS) of substrate and digestates were determined following standard procedures described by the Standard Methods [33] while $\mathrm{pH}$ was measured using a portable $\mathrm{pH}$ meter.

\section{Statistical analyses}

All experiments were performed in triplicates. The digestion process performance data of each reactor were expressed as the mean \pm standard deviation of the samples during the period of operation. An analysis of variance by SPSS (Statistical Package for the Social Science, version 20.0) was employed in this study to test the significance of the results, and $p \leq 0.05$ was considered statistically significant. In addition, coefficient of variation, correlation analysis and comparative description of physicochemical data were carried out using SPSS statistical software at $95 \%$ level of confidence for each test.

\section{Results and discussion}

Effect of manure supplementation on AD performance

The cumulative biochemical methane potential and process performance indicators $(\mathrm{pH}, \mathrm{TS}$ and VS removal) were used to establish the effect of manure supplementation on the performance of the $\mathrm{AD}$ process. Some specific characteristics of individual BSG and POME as well as the AD process performance data are presented in Table 1. From the study, addition of livestock manure resulted in extensive loss in TS and VS contents of the waste mixtures. Following manure seeding, the initial TS and VS contents in waste mixture for reactor $\mathrm{A}$ was 25.4 and $8.1 \%, 21.6$ and $7.3 \%$ for reactor B, 23.4 and $7.9 \%$ for reactor $C$ and 19.0 and $6.9 \%$ for reactor D (control), respectively. The TS content of manure supplemented reactors was higher than that of the control. However, these TS and VS concentrations reduced drastically $(p<0.05)$ at the end of the experiment to 9.6 and $3.8 \%$ (reactor A), 13.5 and $4.6 \%$ (reactor B), 11.2 and $3.8 \%$ (reactor $C$ ) and 17.1 and $6.6 \%$ (reactor D - control), respectively. All manure supplemented reactors gave a higher TS and VS removal efficiency 
indicating the degradative capacity of microbial consortia in manure-based samples in utilizing the organic fraction of the waste. Recently, other authors have reported similar reduction in TS and VS contents during $\mathrm{AD}[11,14]$. The $\mathrm{pH}$ value of the bioreactors ranged between 6.8 to 7.4 at the beginning and 5.2 to 5.7 at the end of the digestion process. This reduction in $\mathrm{pH}$ supports previous findings and may be a consequence of the accumulation of short chain fatty acids which is inimical to methane production [13]. The cumulative biogas and methane yield from reactors A to D of the experimental mixtures were $310 \mathrm{~mL} \mathrm{~g}^{-1} \mathrm{VS}$ and $89.9 \mathrm{~mol} \%, 194 \mathrm{~mL}$ $\mathrm{g}^{-1} \mathrm{VS}$ and $75.7 \mathrm{~mol} \%, 241 \mathrm{~mL} \mathrm{~g}^{-1}$ VS and $81.1 \mathrm{~mol} \%$, $41 \mathrm{~mL} \mathrm{~g}^{-1}$ VS and $59.3 \mathrm{~mol} \%$, respectively (Table 1 ). There was a statistically significant increase $(p<0.05)$ in cumulative biogas and methane yield between the control (non-supplemented) and the supplemented reactors which may have been a function of improved methanogenesis in inoculum supplemented reactors. This increase strongly correlated $(r=0.96)$ with the amount of total anaerobic bacteria in the feedstock. Relative to other inocula, significant biogas and methane yield were obtained with cow dung manure addition. The results (Table 1) reveal that for the initial (feedstock), the level of TS and VS in bioreactor A was significantly higher than that obtained for bioreactor B, C and D $(p<0.05)$ while $\mathrm{TS}$ and $\mathrm{pH}$ in the control were significantly less than that of other groups $(p<0.05)$. For $\mathrm{pH}$, there was no significant difference between that of bioreactor $D$ and $B$ while $A$ and $C$ were significantly higher than that of other reactors $(p<0.05)$. Also, there was significant difference $(p<0.05)$ between the initial and final TS, initial and final VS, and initial and final $\mathrm{pH}$ across all experimental sets. Similarly, Cater et al. [21] recorded significantly elevated biogas and methane production in biogas reactors through manure supplementation. Generally, codigestion improved $\mathrm{pH}$, TS, and VS characteristics with proportionate increase in biogas and biomethane production when compared to single substrate (mono) digestion of either BSG or POME (Table 1). Statistical differences between the results were confirmed using one-way analysis of variance.

\section{Influence of manure supplementation on PGPB populations in anaerobic digestate and their biofertilizing attributes}

Anaerobic digestates were estimated for the presence of cultivable PGPB populations. A comprehensive investigation of the biofertilizing abilities and plant growth promoting characteristics (Table 2) of the estimable indigenous bacterial populations from anaerobic digesters were also carried out. The concentration of PGPB in digestate samples are shown in Fig. 1. From the result, the total PSB (ranging from 1.6-2.5 log CFU
$\mathrm{mL}^{-1}$ ) was significantly higher than the nitrogen fixing bacteria (NFB, $0.5-1.4 \log \mathrm{CFU} \mathrm{mL}^{-1}$ ) across all bioreactors. Supplementation through the addition of livestock manure (as inoculum) significantly increased the populations of these PGPB groups $(p<0.05)$ which differed significantly across all the reactors compared to the control in the following order of abundance: reactor $\mathrm{C}>$ reactor $\mathrm{A}>$ reactor $\mathrm{B}>$ reactor $\mathrm{D}$ (control). The plant growth promoting characteristics of the bacterial isolates are presented in Table 2. The digestate was observed to be a repository of PGPB with remarkable biofertilizing traits as the density of these microbial groups are essential for plant growth. Manure supplementation improved the richness of these microbial groups (Fig. 1) which was a desirable characteristic in the digestate. This assertion supports previous findings by other authors $[9,15,19$, 33, 35]. Apart from the (control reactor) lacking livestock manure amendment, the elevated levels and abundance of PGPB groups (PSB $>$ NFB) in the anaerobic digestate under evaluation was different across the bioreactors in the sequence; reactor $\mathrm{A}>$ reactor $\mathrm{C}>$ reactor $\mathrm{B}>$ reactor $\mathrm{D}$ (control) with a strong positive relationship between NFB and PSB $(r=0.955)$ indicating the consequence of supplementation or bioaugmentation using different livestock manure inocula. The significant increase in the populations of PGPB groups can be attributed to inoculum addition which served as a source of these beneficial bacteria while supplying additional nutrients for their proliferation. It may be said that the biofertilizing quality of anaerobic digestate is a function of the populations of PGPB as well as the nutrient concentration in such digestate [19]. PGPB can encourage plant growth with either of the following mechanisms: bioprotection (suppress plant disease), biofertilization (improve nutrient availability and acquisition) and biostimulation (produce phytohormones) [36].

\section{Effect of $A D$ on microbial load profile of feedstock and digestate}

The results of the microbial load profile of the feedstock and digestate is presented in Fig. 2. It is noteworthy that Vibrio species were completely eliminated at the termination of the AD process. Since all bioreactors were maintained at the same temperature $\left(40^{\circ} \mathrm{C}\right)$ for $30 \mathrm{~d}$ and manure addition was the only changing factor, the subsequent decline in initial concentration of mesophilic bacteria during $\mathrm{AD}$ may be a function of nutrient (substrate) limitation and reactor (feedstock/inoculum) composition rather than the direct effect of temperature and reaction time [38]. Therefore, supplementation with manure had significant influence on the reduction ratios of the studied microbial groups.

At the end of digestion, a general decrease in microbial levels was observed for all bacterial groups across all the 
Table 2 Plant growth promoting properties of bacterial isolates from mesophilic digestate

\begin{tabular}{|c|c|c|c|c|}
\hline Isolate code & Nitrogen fixation & Phosphate solubilization & IAA production & Identified bacteria \\
\hline $\mathrm{A} 1$ & + & + & - & Clostridium sp \\
\hline $\mathrm{A} 2$ & - & + & + & Bacillus sp \\
\hline A3 & - & + & + & Staphylococcus sp \\
\hline A4 & + & + & - & Bacillus sp \\
\hline A5 & - & + & + & Lactobacillus sp \\
\hline A6 & - & + & + & Salmonella sp \\
\hline A7 & + & + & + & Enterobacter sp \\
\hline A8 & - & + & + & Citrobacter sp \\
\hline B1 & + & + & + & Clostridium sp \\
\hline B2 & - & + & + & Staphylococcus sp \\
\hline B3 & + & - & - & Salmonella sp \\
\hline B4 & - & + & + & Pseudomonas sp \\
\hline B5 & - & + & + & Enterobacter sp \\
\hline B6 & + & - & + & Bacillus sp \\
\hline $\mathrm{C} 1$ & - & + & + & Lactobacillus sp \\
\hline$C 2$ & - & + & + & Micrococcus sp \\
\hline $\mathrm{C} 3$ & + & - & + & Bacillus sp \\
\hline C4 & + & + & - & Enterobacter sp \\
\hline $\mathrm{C} 5$ & + & + & + & Clostridium sp \\
\hline $\mathrm{C} 6$ & + & + & + & Bacillus sp \\
\hline $\mathrm{C7}$ & - & - & - & Salmonella sp \\
\hline D1 & + & + & + & Bacillus sp \\
\hline D2 & - & + & + & Staphylococcus sp \\
\hline D3 & + & + & + & Enterobacter sp \\
\hline D4 & - & + & + & Staphylococcus sp \\
\hline D5 & - & + & + & Salmonella sp \\
\hline
\end{tabular}

Key: (+) indicates production activity, (-) indicates non-production activity, A, B, C, D represents reactors and source of isolates

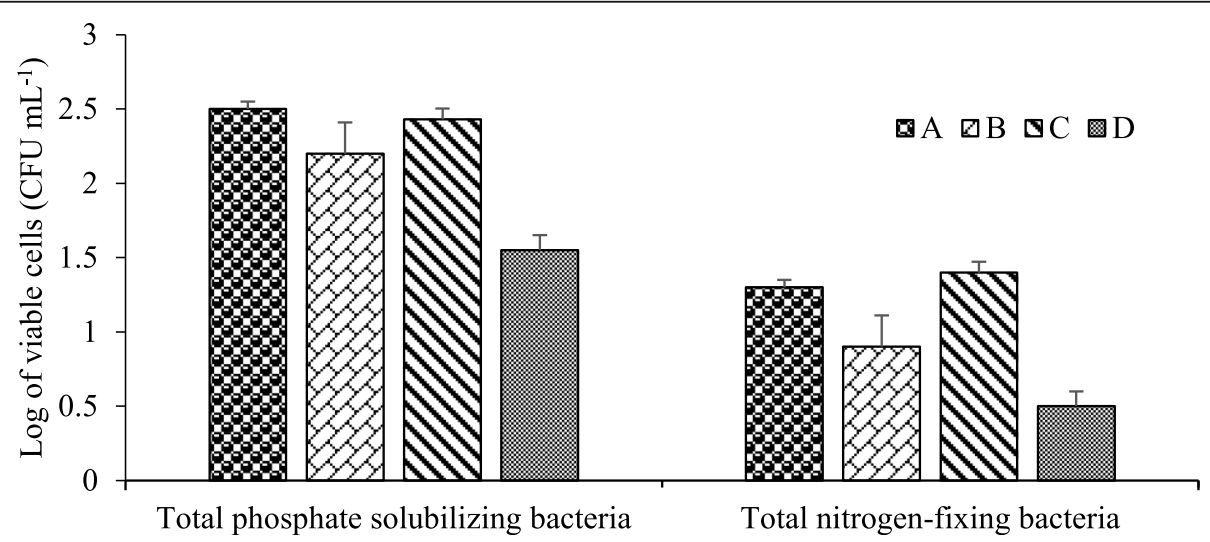

Fig. 1 Populations of phosphate solubilizing and nitrogen-fixing (diazotrophic) bacteria for reactors A, B, C, and D. Error bars indicate standard deviation 


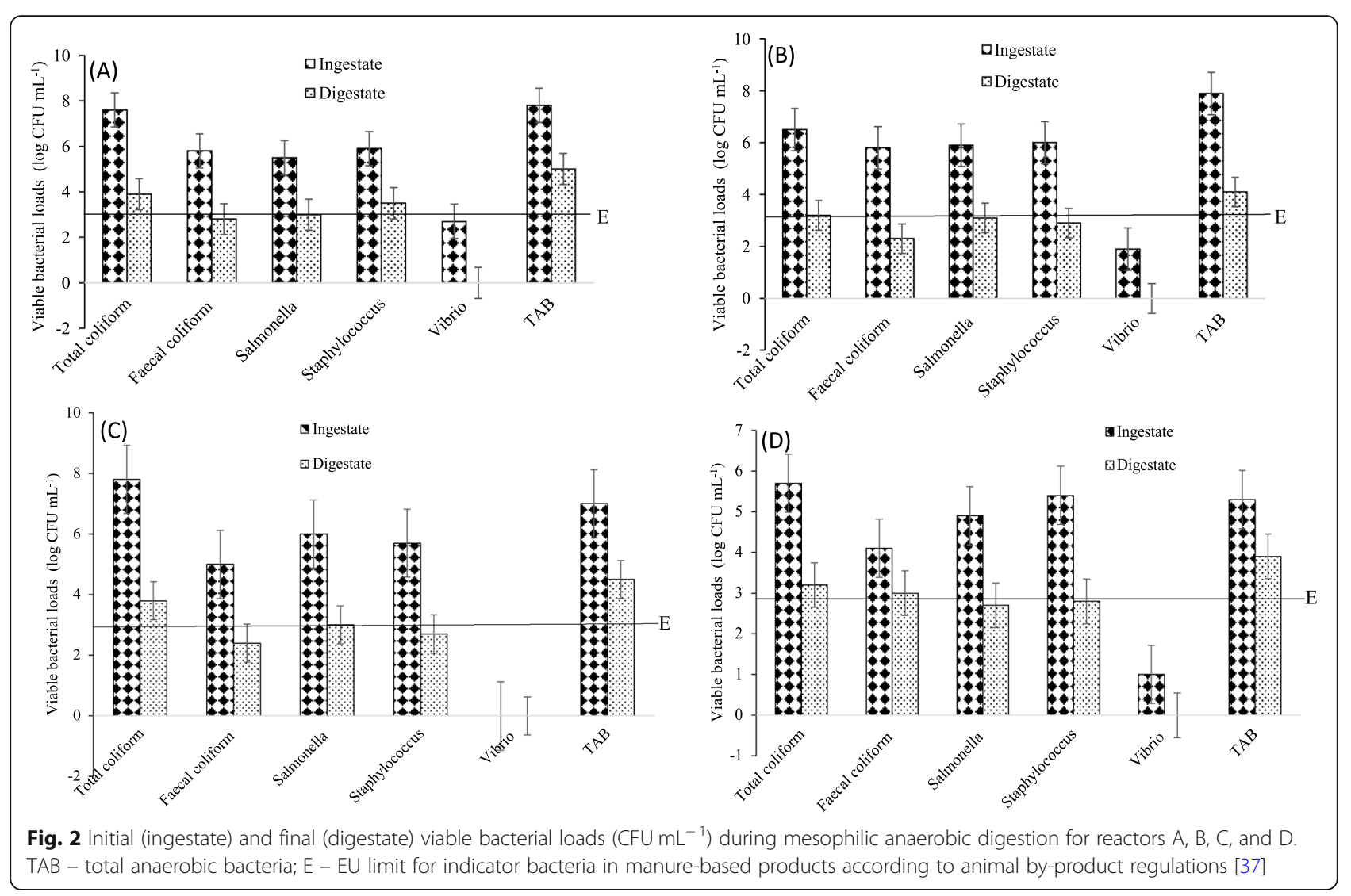

reactors suggesting microbial decay. Averagely across all digesters (Table 3), anaerobic treatment resulted in undetectable levels (99.5\% reduction) of Vibrio species with simultaneous decline in the levels of total coliforms (45\%), faecal coliforms (49\%), Salmonella count (42\%) and Staphylococcus count (46\%) and their relative fractions as illustrated in Fig. 3. This marked reduction was statistically significant $(p<0.05)$ ranging from 0.4 to 1.0 $\log \mathrm{CFU} \mathrm{mL} \mathrm{m}^{-1}$ thus substantiating the earlier report of Alfa et al. [15] who recorded similar trends for coliform count and fungal count. However, Qi et al. [39] recorded a $100 \%$ reduction in all indicator and pathogenic bacteria. These results indicate that laboratory-scale

Table 3 Reduction ratios (\%) of potential pathogens and indicator bacteria in digestate samples

\begin{tabular}{lllll}
\hline Bacterial groups & \multicolumn{4}{l}{ Reactors } \\
\cline { 2 - 5 } & A & B & C & D (control) \\
\hline Total coliforms & $44.4 \pm 0.10^{\mathrm{b}}$ & $46.2 \pm 1.00^{\mathrm{c}}$ & $49.3 \pm 1.00^{\mathrm{d}}$ & $40.0 \pm 1.00^{\mathrm{a}}$ \\
Faecal coliforms & $47.2 \pm 1.00^{\mathrm{b}}$ & $59.2 \pm 1.00^{\mathrm{c}}$ & $60.0 \pm 1.00^{\mathrm{c}}$ & $29.3 \pm 1.00^{\mathrm{a}}$ \\
Salmonella & $36.0 \pm 1.00^{\mathrm{a}}$ & $41.2 \pm 0.81^{\mathrm{b}}$ & $49.2 \pm 1.12^{\mathrm{c}}$ & $40.0 \pm 0.40^{\mathrm{b}}$ \\
Staphylococcus & $36.4 \pm 0.50^{\mathrm{a}}$ & $50.0 \pm 1.00^{\mathrm{b}}$ & $50.0 \pm 5.00^{\mathrm{b}}$ & $46.0 \pm 4.00^{\mathrm{b}}$ \\
Vibrio & $99.6 \pm 0.58^{\mathrm{a}}$ & $99.3 \pm 1.15^{\mathrm{a}}$ & $99.3 \pm 1.15^{\mathrm{a}}$ & $99.6 \pm 0.58^{\mathrm{a}}$ \\
\hline
\end{tabular}

Similar superscript letter means not significantly different in mean $(p>0.05)$, while different superscript letters mean significantly different $(p<0.05)$; A-D indicate bioreactors with different waste composition reactors may be less efficient in pathogen reduction than full-scale biogas plants. Cote et al. [40] studied efficiency of low temperature (psychrophilic) anaerobic treatment in reducing viable populations of indicator microorganisms in pig slurries. These authors reported 1.62 to 4.23 $\log$ CFU $\mathrm{mL}^{-1}$ reduction in populations of indicator organisms thus contradicting the results of this study. This disparity may be attributed to the differences in the treated waste composition, environmental factors, prevailing operating digester condition and digester design. Despite the apparent reduction observed, some indicator bacterial loads were still above the European Union permissible limit of $3.0 \log \mathrm{CFU} \mathrm{mL} \mathrm{m}^{-1}$ for land application of digestate in agriculture [23], indicating that the incubation temperature of $40^{\circ} \mathrm{C}$ and reaction time of $30 \mathrm{~d}$ were insufficient to completely eliminate these potential pathogens in the resultant digestate. Total coliforms load significantly correlated with faecal coliforms $(r=0.924$, $p<0.01)$ and Salmonella loads $(r=0.655, p<0.01)$ while other bacterial groups had no significant relationship with total coliforms $(p>0.05)$. The level of faecal coliforms was not significantly correlated with Salmonella $(r=0.506, p>0.05)$, Staphylococcus $(r=0.334, p>0.05)$ and Vibrio $(r=-0.222, p>0.05)$. There was a significant positive relationship between Salmonella and Vibrio count $(r=0.708, p<0.01)$. 


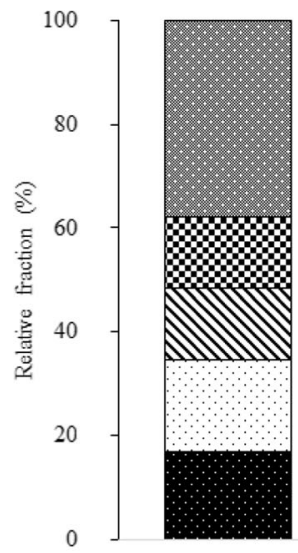

A

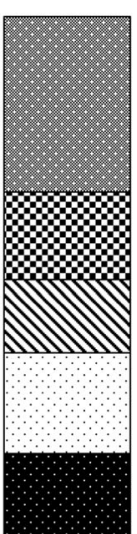

B

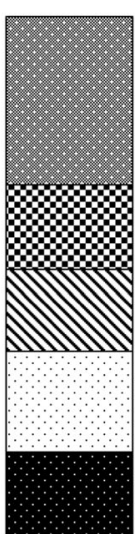

$\mathrm{C}$

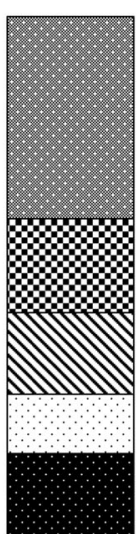

D (control)
Vibrio

Staphylococcus

$\nabla$ Salmonella

$\square$ Faecal coliform

- Total coliform

Fig. 3 Percentage relative fractions of potential pathogens and indicator bacteria during anaerobic digestion. A, B, C indicate manure supplemented reactors, while $\mathrm{D}=$ control

The detection, persistence and survival of indicator bacteria and potential pathogens above the permissible limit after $\mathrm{AD}$ have also previously been documented by other authors [16, 41]. Notably, Qi et al. [18] recorded > $3.0 \log \mathrm{CFU} \mathrm{mL}^{-1}$ in E. coli, Salmonella and Enterococcus loads in mesophilic and thermophilic anaerobic digestates. Similarly, Resende et al. have isolated elevated levels of Enterobacteriaceae, non-fermenting Gram-negative rods and Gram- positive cocci in digestate after $60 \mathrm{~d}$ [24]. This calls for concern as previous studies [23-25] have encountered similar pathogens following $\mathrm{AD}$, most of which have been implicated in foodborne infections. Hence the use of raw and/or untreated livestock manure poses greater risk to consumers of fresh produce than digestate as the survival of pathogens after $\mathrm{AD}$ largely depends on the temperature and reaction time of the substrates in the bioreactors. To overcome this, hygienization and further post-treatment of anaerobic digestate can be obtained at elevated temperatures over an extended retention time [42]. Though not entirely adequate, the reduction in pathogen levels obtained in this study may in part be due to the long reaction time of $30 \mathrm{~d}$. Apart from the effect of temperature on pathogenic organisms, efficient mixing and organic matter stabilisation are additionally important factors controlling the inactivation rate or destruction of pathogens during AD of biowastes [43]. Moreover, the reduction ratio in viable bacteria largely depends on the bacterial species and the initial bacterial load in the feedstock. In this study, the bacterial species encountered at the end of the AD process were facultative anaerobes, strict anaerobes and endosporeforming mesophiles which are not readily destroyed during the mesophilic $\mathrm{AD}$ process as they become hardy, resisting the prevailing milieu in the digesters.

\section{Nutrients and light metals concentrations before and} after $A D$

The concentrations of primary $(\mathrm{N}, \mathrm{P}, \mathrm{K})$ and secondary $(\mathrm{Ca}, \mathrm{Mg}, \mathrm{S})$ plant nutrients are presented in Table 4. From the result, the concentration of $\mathrm{N}$ was detected at higher levels compared to other nutrients ranging from 2.5 to $5.0 \mathrm{~g} \mathrm{~kg}^{-1}$ in the ingestate and 2.7 to $5.10 \mathrm{~g} \mathrm{~kg}^{-1}$ in the digestate. However, the increase in nutrient concentration of all digestate samples was statistically significant $(p<0.05)$. The relative abundance in primary and secondary macronutrients in the samples were as follows; $\mathrm{N}>\mathrm{K}>\mathrm{P}>\mathrm{Ca}>\mathrm{Mg}>\mathrm{S}$ showing an increasing trend as follows: Reactor $\mathrm{C}>$ Reactor $\mathrm{B}>$ Reactor $\mathrm{A}>\mathrm{Re}$ actor D (control).

Nutrient analysis of ingestate (raw substrates) and digestate (effluent) revealed an increase in concentrations of N, P, S, K, Ca and Mg (Table 4). Among these elements, sulphur had the highest variation relative to its mean with the coefficient of variation, $C V=48 \%$ followed by potassium $(C V=39 \%)$ and magnesium $(C V=36 \%)$. In contrast, calcium, nitrogen and phosphorus had the least variability with respect to their mean values and $C V$ ranging from 12 to $23 \%$ ). Across the samples, statistically significant differences were obtained for all the elements analysed indicating a strong influence of the $\mathrm{AD}$ process on the nutrient contents of the digested and undigested waste mixture. From the present study, $\mathrm{AD}$ was identified as an excellent option for nutrient recovery and recycling thus contributing to reducing agricultural cost via the use of inorganic fertilizer. This may in part be due to organic matter decomposition by bacterial consortia during the $\mathrm{AD}$ process. Accordingly, organically bound nutrients become mineralized into readily available forms during digestion. Evidently, $\mathrm{AD}$ tends to increase the contents of readily available nitrogen in the form of ammonium- $\mathrm{N}$, 
Table 4 Nutrient and light metal concentration of feedstock $\left(t_{0}\right)$ and digestate $\left(t_{f}\right)$

\begin{tabular}{|c|c|c|c|c|c|c|c|c|}
\hline \multirow[t]{2}{*}{ Concentration } & \multicolumn{4}{|c|}{ Initial concentration $\left(t_{0}\right)$} & \multicolumn{4}{|c|}{ Final concentration $\left(t_{f}\right)$} \\
\hline & $A_{0}$ & $\mathrm{~B}_{0}$ & $C_{0}$ & $D_{0}$ & $A_{f}$ & $B_{f}$ & $C_{f}$ & $D_{f}$ \\
\hline Total $N\left(\mathrm{~g} \mathrm{~kg}^{-1}\right)$ & $5.00^{b}$ & $3.67^{b}$ & $4.67^{b}$ & $2.50^{\mathrm{b}}$ & $5.10^{c}$ & $3.80^{\mathrm{b}}$ & $4.80^{d}$ & $2.70^{\mathrm{a}}$ \\
\hline Ammonium $\mathrm{N}\left(\mathrm{g} \mathrm{kg}^{-1}\right)$ & $3.5^{\mathrm{b}}$ & $2.0^{\mathrm{a}}$ & $2.8^{c}$ & $1.1^{\mathrm{a}}$ & $3.9^{\mathrm{b}}$ & $2.8^{c}$ & $3.2^{d}$ & $1.98^{\mathrm{a}}$ \\
\hline Phosphorus (mg kg ${ }^{-1}$ ) & $1066^{b}$ & $1086^{b}$ & $1129^{b}$ & $650^{\mathrm{a}}$ & $1133^{c}$ & $1116^{c}$ & $1311^{d}$ & $665^{\mathrm{a}}$ \\
\hline Sulphur $\left(\mathrm{mg} \mathrm{kg}^{-1}\right)$ & $342^{b}$ & $427^{c}$ & $468^{d}$ & $90^{\mathrm{a}}$ & $341^{b}$ & $450^{c}$ & $491^{d}$ & $91.3^{\mathrm{a}}$ \\
\hline Potassium (mg kg ${ }^{-1}$ ) & $1321^{\mathrm{b}}$ & $1290^{b}$ & $1301^{\mathrm{b}}$ & $400^{\mathrm{a}}$ & $1322^{c}$ & $1315^{b}$ & $1334^{d}$ & $411.8^{\mathrm{a}}$ \\
\hline Calcium (mg kg ${ }^{-1}$ ) & $571^{d}$ & $545^{b}$ & $561^{c}$ & $433^{\mathrm{a}}$ & $578^{c}$ & $570^{b}$ & $580^{d}$ & $430.2^{a}$ \\
\hline Magnesium $\left(\mathrm{mg} \mathrm{kg}^{-1}\right)$ & $625^{\mathrm{b}}$ & $621^{\mathrm{b}}$ & $623^{b}$ & $2161^{a}$ & $625^{c}$ & $621^{b}$ & $626^{c}$ & $223.5^{\mathrm{a}}$ \\
\hline
\end{tabular}

Similar superscript letter means not significantly different in mean $(p>0.05)$, while different superscript letters mean significantly different $(p<0.05)$; Total $\mathrm{N}-$ total nitrogen; A-D (Reactors)

and a strong positive correlation between total nitrogen content and total NFB population $(r=0.960)$ was observed. This corroborated the reports of Qi et al. [18] who recorded a significant increase in raw diary manure from $5.3 \mathrm{~g} \mathrm{~kg}^{-1} \mathrm{NH}_{4}-\mathrm{N}$ to $12.2 \mathrm{~g} \mathrm{~kg}^{-1}$ in thermophilic anaerobic digestates. Moller and Muller [44] reported an increase in concentrations of $\mathrm{NH}_{4}-\mathrm{N}$ by 45 to $80 \%$ following $\mathrm{AD}$. Likewise, Coelho and other authors recorded an increase in concentration of macronutrients [33, 39]. Like nitrogen, phosphorus may be present in organic or inorganic form in anaerobic digestate. In this study, the total phosphorus concentration in the digestate samples ranged between 1116 and $1310 \mathrm{mg} \mathrm{kg}^{-1}$ in inoculum amended reactors and was 1.78 times higher than contents measured in control bioreactors (Table 4). This difference was found to be significant $(p<0.05)$ alluding to the influence of manure addition on the nutrient property of anaerobic digestate. Potassium, another key nutrient to be supplied by soil conditioner, is often found in inorganic form. The potassium contents measured in the control and manure-supplemented bioreactors showed significant differences $(p<0.05)$ with values ranging from 400 to $1332 \mathrm{mg} \mathrm{kg}^{-1}$. This amount may be considered high when compared to potassium levels $(36.75 \mathrm{mg}$ $\mathrm{L}^{-1}$ ) reported by Quintanar-Orozco et al. [19] in digestate (biofertilizer) derived from Opuntia heliabravoana cladodes. Potassium is a macroelement that is of fundamental importance and plays a vital role in the water balance of plants, activation of enzymes and participates in photosynthetic processes among other functions. It is noteworthy to state that there exists a strong positive association between potassium and calcium contents $(r=$ $0.999)$ as well as magnesium and calcium $(r=0.998)$. The concentrations of $\mathrm{Ca}$ and $\mathrm{Mg}$ were higher in the livestock manure amended bioreactors and were respectively 1.33 and 2.79 times significantly higher than the reactors with no livestock manure amendment (control). These levels are however lower than those reported by Alburquerque et al. [35]. Altogether, Qi et al. [18] have stated that $\mathrm{N}, \mathrm{P}, \mathrm{K}$ nutrients contribute most to the fertilizing properties of organic soil amendment as these are the primary plant nutrients. These essential elements (NPK) are required by plants in higher quantities than other secondary $(\mathrm{Ca}, \mathrm{Mg}, \mathrm{S})$ and micronutrients $(\mathrm{Pb}, \mathrm{Ni}$, $\mathrm{Zn}, \mathrm{Cu}, \mathrm{Cr}, \mathrm{Hg}, \mathrm{Cd})$.

\section{Potentially toxic elements concentrations of feedstock and digestate}

The potentially toxic element concentration of the various feedstock compositions (reactors A to D) and digestate are compared in Table 5 . There was a general reduction in heavy metal concentrations in the digestate samples although it was not significant at $p=0.05$. Compared to other elements, zinc was the most abundant across all the samples ranging between 15 and $57 \mathrm{mg}$ $\mathrm{kg}^{-1}$. However, chromium, mercury and cadmium were below the detection level of $<0.01 \mathrm{mg} \mathrm{kg}^{-1}$ in all samples.

The recycling of nutrients present in biomass feedstock may also pose the risk of toxic metals in the digestate meant for environmental application. The toxic and harmful effects of these metals are not limited to plants and microbes but include humans also. This concern therefore limits the safe utilization of digestate in soils and crops. Generally, studies piloted by several researchers $[9,33,34,39]$ revealed a decreasing trend in the concentrations of PTEs in digestate samples within the recommended limits [45] of publicly available specifications (PAS-110). This decreasing trend was in conformity with the concentrations of $\mathrm{Pb}, \mathrm{Ni}, \mathrm{Zn}$ and $\mathrm{Cu}$ obtained in this study and was in line with the PAS-110 standard for the safe application of digestate on land. Moreover, $\mathrm{Cr}, \mathrm{Hg}$ and $\mathrm{Cd}$ concentrations were below the detection levels of $<0.01 \mathrm{mg} \mathrm{kg}^{-1}$ each (Table 4). The reduction in metal concentration of the digestate samples may be a result of the role of PGPB in metal hyperaccumulation and sequestration during the digestion process [46].

The PTE concentrations revealed a high degree of variability $(C V=0-81 \%)$ suggesting a significant 
Table 5 Heavy metal concentrations in feedstock $\left(t_{0}\right)$ and digestate $\left(t_{f}\right)$

\begin{tabular}{|c|c|c|c|c|c|c|c|c|c|}
\hline \multirow{2}{*}{$\begin{array}{l}\text { Concentration } \\
\left(\mathrm{mg} \mathrm{kg}^{-1}\right)\end{array}$} & \multicolumn{4}{|c|}{ Initial concentration $\left(t_{0}\right)$} & \multicolumn{4}{|c|}{ Final concentration $\left(t_{f}\right)$} & \multirow[b]{2}{*}{ PAS110 } \\
\hline & $A_{0}$ & $\mathrm{~B}_{0}$ & $C_{0}$ & $D_{0}$ & $A_{f}$ & $B_{f}$ & $C_{f}$ & $D_{f}$ & \\
\hline Lead & $4.0 \pm 1.00^{b}$ & $4.3 \pm 0.12^{b}$ & $2.6 \pm 0.10^{a}$ & $2.3 \pm 0.00^{\mathrm{a}}$ & $\mathrm{BDL}$ & $3.6 \pm 0.10^{c}$ & $\mathrm{BDL}$ & $2.3 \pm 0.10^{b}$ & 200 \\
\hline Nickel & $10.5 \pm 0.10^{b}$ & $11.3 \pm 0.55^{b}$ & $12.5 \pm 1.00^{b}$ & $6.3 \pm 0.55^{\mathrm{a}}$ & $2.3 \pm 0.10^{a}$ & $4.4 \pm 0.10^{d}$ & $3.5 \pm 0.20^{b}$ & $5.3 \pm 0.00^{c}$ & 50 \\
\hline Zinc & $49.2 \pm 1.10^{b}$ & $51.3 \pm 0.85^{c}$ & $57.9 \pm 1.01^{d}$ & $45.5 \pm 0.55^{\mathrm{a}}$ & $15.2 \pm 0.32^{\mathrm{a}}$ & $27.2 \pm 1.00^{b}$ & $29.3 \pm 0.63^{c}$ & $40.1 \pm 0.15^{d}$ & 400 \\
\hline Copper & $3.7 \pm 0.10^{b}$ & $5.4 \pm 0.10^{c}$ & $4.0 \pm 1.00^{b}$ & $2.5 \pm 0.20^{a}$ & $0.9 \pm 0.08^{b}$ & $3.1 \pm 0.10^{c}$ & $\mathrm{BDL}$ & $\mathrm{BDL}$ & 200 \\
\hline Chromium & $\mathrm{BDL}$ & $\mathrm{BDL}$ & $\mathrm{BDL}$ & $\mathrm{BDL}$ & ND & ND & ND & ND & 100 \\
\hline Mercury & $\mathrm{BDL}$ & $\mathrm{BDL}$ & $\mathrm{BDL}$ & $\mathrm{BDL}$ & ND & ND & ND & ND & 1.0 \\
\hline Cadmium & $\mathrm{BDL}$ & $\mathrm{BDL}$ & $\mathrm{BDL}$ & $\mathrm{BDL}$ & ND & ND & ND & ND & 1.5 \\
\hline
\end{tabular}

Similar superscript letter means not significantly different in mean $(p>0.05)$, while different superscript letters mean significantly different $(p<0.05)$; PAS110 Publicly available specification according to British Standard Institute [44]; BDL - Below detection level; ND - Not determined; A - D (Reactors). Minimum detection limit $-0.01 \mathrm{mg} \mathrm{kg}^{-1}$

influence $(p<0.05)$ of the waste feedstock on the heavy metal characteristics of the digestate. The concentration of these metals was generally lower in the digestate than in the undigested raw feedstock although this difference was however statistically not significant $(p>0.05)$. Besides being potentially harmful to microbes, plants and humans, plant micronutrients are necessary for plant growth and development but are needed in minute quantities.

\section{Conclusions}

Using different livestock manure as inoculum, the effect of manure supplementation on the biofertilizer quality of anaerobic digestate was investigated. Results indicated that manure addition enhanced the biofertilizing properties of the resultant digestion residue with poultry manure giving the highest result in terms of its PGPB and nutrient composition. Besides serving as a depository of numerous beneficial microbial groups and plant nutrients, the digestates also harboured notable indicator bacteria and potential pathogens with miniscule amount of potentially toxic elements. However, as a biological soil amendment or conditioner, evaluation of the biosafety risk and post treatment (hygienization) of any digestate should be encouraged before its land application as potential contamination of fresh produce by pathogenic bacteria through the application of anaerobic digestate is of concern.

\section{Acknowledgments}

We are thankful to the laboratory staff of Laser Geoscience Engineering, Port Harcourt, Nigeria for performing some of the analyses documented in this work.

\section{Authors' contributions}

All the authors have contributed to the structure, content, and writing of the paper. All authors read and approved the final manuscript.

\section{Funding}

The authors are grateful to the University of Uyo for partly supporting this work through the Postgraduate Grant (UU/PF/NOL.I/23) awarded to Mr. Utibe A. Ofon.
Availability of data and materials

No such sources of data or materials were used for this study.

\section{Competing interests}

None.

\section{Author details}

${ }^{1}$ Department of Microbiology, University of Uyo, Uyo 520001, Nigeria. ${ }^{2}$ International Centre for Energy \& Environmental Sustainability Research, University of Uyo, Uyo 520001, Nigeria. ${ }^{3}$ Present address: College of New Energy \& Environment, Jilin University, Changchun City 130021, China.

Received: 18 February 2020 Accepted: 15 June 2020

Published online: 24 June 2020

\section{References}

1. Oliveira JV, Alves MM, Costa JC. Biochemical methane potential of brewery by-products. Clean Technol Envir. 2018;20:435-40.

2. Ohimain El, Izah SC. A review of biogas production from palm oil mill effluents using different configurations of bioreactors. Renew Sust Energ Rev. 2017;70:242-53.

3. Chin KL, Nurliyana MY, H'ng PS, Lee CL, Go WZ, Khoo PS, et al. Effects of bacterial bio-augmentation on the methane potential from facultative digestion of palm oil mill effluent and empty fruit bunch. Waste Biomass Valor. 2019. https://doi.org/10.1007/s12649-019-00680-3.

4. Mpofu AB, Welz PJ, Oyekola OO. Anaerobic digestion of secondary tannery sludge: optimisation of initial $\mathrm{pH}$ and temperature and evaluation of kinetics. Waste Biomass Valor. 2020;11:873-85.

5. Shah TA, Ullah R. Pretreatment of wheat straw with ligninolytic fungi for increased biogas productivity. Int J Environ Sci Technol. 2019;16:7497-508.

6. Nkoa R. Agricultural benefits and environmental risks of soil fertilization with anaerobic digestates: a review. Agron Sustain Dev. 2014;34:473-92.

7. Bauer A, Mayr H, Hopfner-Sixt K, Amon T. Detailed monitoring of two biogas plants and mechanical solid-liquid separation of fermentation residues. J Biotechnol. 2009;142:56-63.

8. Khalid A, Arshad M, Anjum M, Mahmood T, Dawson L. The anaerobic digestion of solid organic waste. Waste Manag. 2011;31:1737-44.

9. Mukhubau M, Roopnarain A, Adeleke R, Moeletsi M, Makofane R. Comparative assessment of bio-fertiliser quality of cow dung and anaerobic digestion effluent. Cogent Food Agr. 2018;4:1435019.

10. Liu GQ, Zhang RH, El-Mashad HM, Dong RJ. Effect of feed to inoculum ratios on biogas yields of food and green wastes. Bioresour Technol. 2009; 100:5103-8.

11. Kovacic D, Kralik D, Jovicic D, Rupcic S, Popovic B, Tisma M. Thermal pretreatment of harvest residues and their use in anaerobic co-digestion with dairy cow manure. Appl Biochem Biotech. 2018;184:471-83.

12. Eduok $\mathrm{S}$, John $\mathrm{O}$, Ita B, Inyang $\mathrm{E}$, Coulon F. Enhanced biogas production from anaerobic co-digestion of lignocellulosic biomass and poultry feces using source separated human urine as buffering agent. Front Env Sci-Switz. 2018;6:67. 
13. Kainthola J, Kalamdhad AS, Goud W. Enhanced methane production from anaerobic co-digestion of rice straw and Hydrilla verticillata and its kinetic analysis. Biomass Bioenergy. 2019;125:8-16.

14. Tayyab A, Ahmad Z, Mahmood T, Khalid A, Qadeer S, Mahmood S, et al. Anaerobic co-digestion of catering food waste utilizing Parthenium hysterophorus as co-substrate for biogas production. Biomass Bioenergy. 2019;124:74-82

15. Alfa Ml, Adie DB, Igboro SB, Oranusi US, Dahunsi SO, Akali DM. Assessment of biofertilizer quality and health implications of anaerobic digestion effluent of cow dung and chicken droppings. Renew Energ. 2014;63:681-6.

16. Bonetta S, Bonetta S, Ferretti E, Fezia G, Gilli G, Carraro E. Agricultural reuse of the digestate from anaerobic co-digestion of organic waste: microbiological contamination, metal hazards and fertilizing performance. Water Air Soil Poll. 2014;225:2046.

17. Risberg K, Cederlund H, Pell M, Arthurson V, Schnturer A. Comparative characterization of digestate versus pig slurry and cow manure - chemical composition and effects on soil microbial activity. Waste Manag. 2017;61: 529-38

18. Qi GD, Pan ZF, Sugawa Y, Andriamanohiarisoamanana FJ, Yamashiro T, Iwasaki M, et al. Comparative fertilizer properties of digestates from mesophilic and thermophilic anaerobic digestion of dairy manure: focusing on plant growth promoting bacteria (PGPB) and environmental risk. J Mater Cycles Waste. 2018;20:1448-57.

19. Quintanar-Orozco ET, Vazquez-Rodriguez GA, Beltran-Hernandez RI, LuchoConstantino CA, Coronel-Olivares C, Montiel SG, et al. Enhancement of the biogas and biofertilizer production from Opuntia heliabravoana Scheinvar. Environ Sci Pollut R. 2018;25:28403-12.

20. Goberna M, Camacho MD, Lopez-Abadia JA, Garcia C. Co-digestion, biostimulation and bioaugmentation to enhance methanation of brewer's spent grain. Waste Manage Res. 2013;31:805-10.

21. Cater M, Fanedl L, Malovrh S, Logar RM. Biogas production from brewery spent grain enhanced by bioaugmentation with hydrolytic anaerobic bacteria. Bioresour Technol. 2015;186:261-9.

22. Li LH, Li Y, Sun YM, Yuan ZH, Kang XH, Zhang Y, et al. Effect of bioaugmentation on the microbial community and mono-digestion performance of Pennisetum hybrid. Waste Manag. 2018;78:741-9.

23. McCarthy G, Lawlor PG, Gutierrez M, Gardiner GE. Assessing the biosafety risks of pig manure for use as a feedstock for composting. Sci Total Environ. 2013:463:712-9

24. Resende JA, Silva VL, de Oliveira TLR, Fortunato SD, Carneiro JD, Otenio MH, et al. Prevalence and persistence of potentially pathogenic and antibiotic resistant bacteria during anaerobic digestion treatment of cattle manure. Bioresour Technol. 2014;153:284-91.

25. Manyi-Loh CE, Mamphweli SN, Meyer EL, Okoh Al, Makaka G, Simon M. Inactivation of selected bacterial pathogens in dairy cattle manure by mesophilic anaerobic digestion (balloon type digester). Int J Env Res Pub He. 2014:11:7184-94.

26. Holt JG, Krieg NR, Sneath PHA, Staley JT, Williams ST. Facultatively anaerobic gram-negative rods. In: Hensyl WR, editor. Bergey's manual of determinative bacteriology. 9th ed. Philadelphia: Lippincott Williams \& Wilkins; 2000. p. 175-290.

27. Chung H, Park M, Madhaiyan M, Seshadri S, Song J, Cho H, et al. Isolation and characterization of phosphate solubilizing bacteria from the rhizosphere of crop plants of Korea. Soil Biol Biochem. 2005;37:1970-4.

28. Vimal SR, Patel VK, Singh JS. Plant growth promoting Curtobacterium albidum strain SRV4: an agriculturally important microbe to alleviate salinity stress in paddy plants. Ecol Indic. 2019;105:553-62.

29. Khamna S, Yokota A, Lumyong S. Actinomycetes isolated from medicinal plant rhizosphere soils: diversity and screening of antifungal compounds, indole-3-acetic acid and siderophore production. World J Microb Biot. 2009; 25:649-55.

30. Hamza TA, Hussein Z, Mitku R, Ayalew P, Belayneh T. Isolation and characterization of nitrogen fixing bacteria from rhizospher soil collected from Shell Mele agricultural center, southern Ethiopia. J Agric Sci Food Technol. 2017:3:117-24.

31. Shrivastava UP, Kumar A. A simple and rapid plate assay for the screening of indole-3-acetic acid (IAA) producing microorganisms. Int J Appl Biol Pharm. 2011;2:120-3

32. Cheesbrough M. District laboratory practice in tropical countries. Part 2. 2nd ed. Cambridge: Cambridge University Press; 2006.

33. APHA. Standard methods for the examination of water and wastewater 14th ed. Washington, DC: American Public Health Association; 2005.
34. Kataki S, Hazarika S, Baruah DC. Assessment of by-products of bioenergy systems (anaerobic digestion and gasification) as potential crop nutrient. Waste Manag. 2017;59:102-17.

35. Alburquerque JA, de la Fuente C, Ferrer-Costa A, Carrasco L, Cegarra J, Abad $M$, et al. Assessment of the fertiliser potential of digestates from farm and agroindustrial residues. Biomass Bioenergy. 2012;40:181-9.

36. Patel MV, Patel RK. Indole-3-acetic acid (IAA) production by endophytic bacteria isolated from saline dessert, the little Runn of Kutch. CIBTech J Microbiol. 2014;3:17-28.

37. European Union. Commission regulation (EU) no 142/2011 of 25 February 2011 implementing regulation (EC) no 1069/2009 of the European Parliament and of the council laying down health rules as regards animal by-products and derived products not intended for human consumption and implementing council directive 97/78/EC as regards certain samples and items exempt from veterinary checks at the border under that directive. Official J Eur Union. 2011;54:1-254.

38. Thomas C, Idler C, Ammon C, Herrmann C, Amon T. Inactivation of ESBL -/AmpC-producing Escherichia coli during mesophilic and thermophilic anaerobic digestion of chicken manure. Waste Manag. 2019;84:74-82.

39. Qi GD, Pan ZF, Yamamoto Y, Andriamanohiarisoamanana FJ, Yamashiro T, Iwasaki $M$, et al. The survival of pathogenic bacteria and plant growth promoting bacteria during mesophilic anaerobic digestion in full-scale biogas plants. Anim Sci J. 2019;90:297-303.

40. Cote C, Masse DI, Quessy S. Reduction of indicator and pathogenic microorganisms by psychrophilic anaerobic digestion in swine slurries. Bioresour Technol. 2006;97:686-91.

41. Coelho JJ, Prieto ML, Dowling S, Hennessy A, Casey I, Woodcock T, et al. Physical-chemical traits, phytotoxicity and pathogen detection in liquid anaerobic digestates. Waste Manag. 2018;78:8-15.

42. Astals S, Venegas C, Peces M, Jofre J, Lucena F, Mata-Alvarez J. Balancing hygienization and anaerobic digestion of raw sewage sludge. Water Res. 2012;46:6218-27.

43. Smith SR, Lang NL, Cheung KHM, Spanoudaki K. Factors controlling pathogen destruction during anaerobic digestion of biowastes. Waste Manag. 2005:25:417-25.

44. Moller K, Muller T. Effects of anaerobic digestion on digestate nutrient availability and crop growth: a review. Eng Life Sci. 2012;12:242-57.

45. BSI. Specification for whole digestate, separated liquor and separated fibre derived from the anaerobic digestion of source-segregated biodegradable materials. London: British Standards Institution; 2010. p. 27-40.

46. Kong ZY, Glick BR. The role of plant growth-promoting bacteria in metal phytoremediation. Adv Microb Physiol. 2017;71:97-132.

\section{Publisher's Note}

Springer Nature remains neutral with regard to jurisdictional claims in published maps and institutional affiliations.

\section{Ready to submit your research? Choose BMC and benefit from:}

- fast, convenient online submission

- thorough peer review by experienced researchers in your field

- rapid publication on acceptance

- support for research data, including large and complex data types

- gold Open Access which fosters wider collaboration and increased citations

- maximum visibility for your research: over $100 \mathrm{M}$ website views per year

At $\mathrm{BMC}$, research is always in progress.

Learn more biomedcentral.com/submission 